\title{
Phonological awareness and early reading and writing abilities in early childhood education: preliminary normative data
}

\author{
Camila Barbosa Riccardi León ${ }^{1}$ \\ https://orcid.org/0000-0002-3392-992X \\ Ágata Almeida ${ }^{2}$ \\ https://orcid.org/0000-0002-1899-4803 \\ Sandra Lira ${ }^{2}$ \\ https://orcid.org/0000-0002-0618-4061 \\ Grace Zauza ${ }^{2}$ \\ https://orcid.org/0000-0001-9264-4679 \\ Talita de Cássia Batista Pazeto ${ }^{1}$ \\ https://orcid.org/0000-0003-3663-2205 \\ Alessandra Gotuzo Seabra ${ }^{1}$ \\ https://orcid.org/0000-0002-8373-7897 \\ Natália Martins Dias ${ }^{2}$ \\ https://orcid.org/0000-0003-1144-5657
}

Universidade Presbiteriana Mackenzie, São Paulo, São Paulo, Brasil.

Centro Universitário FIEO - Fundação Instituito de Ensino para Osasco, Osasco, São Paulo, Brasil.

Universidade Federal de Santa Catarina UFSC, Florianópolis, Santa Catarina, Brasil.

Research support sources: Coordination for the Improvement of Higher Education Personnel - CAPES (authors: CBRL, $A A, S L, G Z$ and TCBP) and the National Council for Scientific and Technological Development - CNPq (authors: AGS and NMD).

Conflict of interests: Nonexistent

\section{(c) (i)}

Received on: May 22, 2018 Accepted on: February 5, 2019

Corresponding address:

Camila Barbosa Riccardi León

Rua Vinte e Cinco de Janeiro, 151,

Apto.82, BI A1. Luz

CEP: 01103-000 - São Paulo, São Paulo, Brasil

E-mail: camilaleon30@gmail.com

\section{ABSTRACT}

Objective: to provide preliminary normative data for the Reading and Writing Test by type of school, and normative data for the Phonological Awareness Test by Oral Production for private schools and update their normative data available for public schools, all of which are for children in the final year of early childhood education.

Methods: 267 children, in the age range of 5 years, and typical development. Identification Questionnaire for Parents, Phonological Awareness Test by Oral Production and Reading and Writing Test were used. The means of performance in the tests of the present sample were compared with the existing normative data to justify normative data provision and updating.

Results: student's t-test revealed that the private school children outperformed those of the public schools in all measures, reinforcing the need for specific standards, according to the type of school. There were strong to very strong relationships among the variables evaluated, demonstrating a marked association between phonological awareness and initial reading and writing abilities. The Wilcoxon test revealed significant differences between the performance of the children of the present study, from both private and public schools, and the data from the Phonological Awareness Test by Oral Production standardization sample, suggesting the need to update the Phonological Awareness Test by Oral Production standards. Finally, the new normative data were presented.

Conclusion: the need to make available and update the test standards used, according to the type of school, was confirmed. Further studies are necessary to expand the data presented to other age groups.

Keywords: Language; Preschool; Literacy; Academic Performance 


\section{INTRODUCTION}

The acquisition of written language is one of the great achievements of childhood, which forms the basis for other learning and has a direct impact on subsequent academic success ${ }^{1,2}$. Professionals from different areas, such as psychology, speech therapy, psychopedagogy and pedagogy, seek to understand the processes involved in the acquisition of written language ${ }^{1-5}$, as well as to make available and improve assessment and intervention instruments, in order to help identify and intervene in learning difficulties in this area. However, with regard to the early evaluation and identification of children at risk of future difficulties in the acquisition of written language, there is still a relative scarcity of evaluation instruments, especially non-restricted ones, available on the national market ${ }^{6,7}$.

Learning to read and write effectively demands the prior acquisition of abilities such as knowledge of the letters and sounds of the alphabet; phonological awareness (ability to store and manipulate speech sounds); rapid serial naming of letters, digits, objects or colors (ability to quickly name random symbol sequences); writing the name; and vocabulary and phonological memory (ability to store phonological information for a short period of time) $)^{1,8-11}$. There is evidence that these abilities are under development in children between 3 and 6 years of age, with a series effect already observed in Early Childhood Education ${ }^{12-14}$. However, although they seem simple and natural, such pre-literacy abilities require daily stimulation to be acquired, and should occur in Early Childhood Education, prior to the formal process of acquisition of written language ${ }^{15,16}$.

Among the abilities cited above, the knowledge of the letters and sounds of the alphabet, plus the ability to encode/write and decode/read letters, syllables or isolated words should be highlighted as initial reading and writing abilities ${ }^{17-20}$. Several studies suggest a strong relationship between knowledge of the letters of the alphabet and success in the initial learning of the written language ${ }^{1,17,21-24}$. In this line of research, Pazeto et al..$^{17}$ investigated initial reading and writing abilities in 90 children, with a mean age of 4 years and 9 months, from a private elementary school in São Paulo. The children were evaluated in oral language abilities (phonological awareness, phonological memory, receptive vocabulary and naming) and initial reading and writing abilities (reading and writing of words and pseudowords). The results showed that these abilities tend to develop rapidly over a year of schooling, and that they present statistical within-domain associations (performance in tests that evaluate the same construct) and between-domain associations (performance in tests that evaluate many different constructs). Among the within-domain associations, there was a strong relationship between knowledge of sounds and initial reading and writing abilities. Among the betweendomain associations, there was a relationship between all abilities, with the exception of rapid serial naming (for word repetition), with a prominent role for the strong relationships between phonological awareness and initial reading and writing abilities. In addition to supporting developmental data and patterns of the relationship between oral and written language, the study by Pazeto et al. ${ }^{17}$ provided the Reading and Writing Tasks and the Speech Recognition Task as standardized alternatives for the evaluation of initial reading and writing abilities for children at the beginning of literacy. Despite the relevant contributions to the literature of the area, the study by Pazeto et al. ${ }^{17}$ did not present normative data for the Reading and Writing Tasks, with one of its limitations being that the sample was only from a private school.

The type of school seems to influence the performance of children in standardized tests. Some studies $^{25-28}$ have identified that children in private schools tend to perform better in cognitive abilities (reading, writing, and language) compared to children in public schools. For example, Silva et al. ${ }^{25}$ found that children of a private school performed better in rapid and written serial naming than those of a public school. The influence of socio-educational aspects was identified, especially in relation to the number of books at home and to reading habits. Half of the children in the public school had 0 to 3 books at home, while those in the private school had more than 6 books. In addition, the majority of the parents of the private school frequently read with their children, while this was performed by the minority of the parents of the public school children. In accordance with these findings, the differences observed in the sample of the present study justify the provision of independent standards for children of each type of school.

Considering the possible differences in performance in oral and written language abilities among public and private school students, some evaluation instruments provide standards that are stratified according to the type of school, with it being rare to find them in non-restricted instruments. One of the few examples available on the national market is the 
School Performance Test $^{29}$ which assesses reading (recognition of words isolated from the context), writing (writing their own names and dictation of words) and arithmetic (oral problem solving and written calculation). It has normative data for students from the $1^{\text {st }}$ to $6^{\text {th }}$ grade of Elementary Education (old classification of the education system, currently corresponds from $2^{\text {nd }}$ year to $7^{\text {th }}$ year of Elementary Education) of municipal, state and private schools. Although mentioned here as an example, the School Performance Test is not suitable for the evaluation of precursor or pre-academic abilities in the pre-literacy stage. The other non-restricted oral and written language assessment tools generally provide standards for public schools, such as the collection "Cognitive Neuropsychological Assessment", volume $2^{30}$ and volume $3^{31}$. Thus, there is a gap in the literature, suggesting a need for new studies that could provide specific standards according to the type of school for other tests available on the national market.

Another issue that needs to be highlighted in relation to the standardization of evaluation instruments is the importance of their updating ${ }^{32,33}$. For example, taking as a parameter the particular area of psychological evaluation, it is necessary for the psychometric properties of an instrument to be reviewed periodically, allowing a maximum interval of 15 years between the standardization studies and 20 years for validity and reliability studies $^{32}$. Again using the School Performance Test as an example, this is one of the instruments that is undergoing studies to update its psychometric evidence, as suggested by Knijnik et al. ${ }^{34}$ and Giacomoni et al. ${ }^{35}$. Some tests available in the collections "Cognitive Neuropsychological Assessment" volume $2^{30}$ and volume $3^{31}$ are already under study to update their psychometric properties, including normative data.

Considering the few instruments available in this area, the relevance of phonological awareness and initial reading and writing abilities as predictors of later performance in the literacy stage and the impact of the type of school on the performance of the measures analyzed $^{26,27}$, the aims of this study were to provide preliminary normative data for the Reading and Writing Test by type of school, to provide normative data for the Phonological Awareness Test by Oral Production for private schools and to update its normative data available for public schools, all of which are for children in the final year of Early Childhood Education.

\section{METHODS}

\section{Procedure}

The present study compiles data from two research projects approved respectively by the Research Ethics Committee (REC) of the Mackenzie Presbyterian University and the REC of the FIEO University Center (Foundation Institute of Education for Osasco), one performed in a private school (CAAE No. 02631312.3.0000.0084) and the other one carried out in two public schools (CAAE no. 42048414.0.1001.5435). In both, the procedure adopted was the same, that is, contact with the school and referral to the head of the school and parents/guardians of the terms of consent and information on how the study would be conducted. The collection took place in the first semester of the school year, by a team previously trained in the application of each instrument. After consent was given by the parents, the Identification Questionnaire for Parents was sent to them. The children responded individually to the tests during school time, in a reserved room at their own school. Initially the Phonological Awareness Test by Oral Production was applied and later the Reading and Writing Tasks, with all the children. Two sessions with each student were required to apply the tests in order to avoid causing fatigue in the children. Each session lasted approximately 20 minutes.

\section{Participants}

Initially, 287 children from the final year of Early Childhood Education, with a mean age of 5 years, enrolled in three schools, one private and two municipal schools in greater São Paulo, were selected for the study. According to the curriculum guidelines of the private school, in the final year of Early Childhood Education the formal introduction of instructions on written language begins, with activities based on the letters of the alphabet and their sounds. In the public schools, the teaching of letters of the alphabet was less systematic and there were no explicit instructions on the sounds of the letters.

As the Phonological Awareness Test by Oral Production $^{36}$ has normatization by age and considering the small number of children of 4 and 6 years $(N$ $=14)$ in the sample, the age of 5 years was stipulated as an inclusion criterion. Exclusion criteria included the presence of indicators of intellectual disability, syndromic, psychiatric or neurological conditions and/or developmental changes, including language, identified through the application of the Identification 
Questionnaire for Parents and consultation of the school records. Thus, six children were excluded from the sample, two with Down's Syndrome, three with a diagnostic hypothesis of Autism Spectrum Disorder and one who did not communicate orally with the researchers. The final sample consisted of 267 children, as shown in Table 1. Student's t-test revealed that there was no age difference $(t=-1.48, p=0.14)$ between the children from the public and private schools.

Table 1. Characteristics of the total sample by type of school

\begin{tabular}{cccccc}
\hline \multirow{2}{*}{ Type of school } & \multirow{2}{*}{ N } & \multicolumn{2}{c}{ Age (months) } & \multicolumn{2}{c}{ Gender (\%) } \\
\cline { 2 - 6 } & & Mean & SD & Males & Females \\
\hline Private & 100 & 64.98 & 3.39 & 52.0 & 48.0 \\
Public & 167 & 65.62 & 3.46 & 55.7 & 44.3 \\
\hline Total & 267 & 65.38 & 3.44 & 54.3 & 45.7 \\
\hline
\end{tabular}

\section{Instruments}

Identification Questionnaire for Parents: This questionnaire was designed by the authors and aims to collect data for the identification and characterization of the sample, according to the parents' reports. It consists of 31 items, including 7 child identification items, 16 parent identification items and 8 items about the development of the child. This questionnaire helped in the identification of the exclusion criteria in the study participants. The time for completion is estimated at 10 to 15 minutes.

Phonological Awareness Test by Oral Production $^{36}$ : This individual application instrument evaluates the subjects' ability to mentally manipulate speech sounds by means of oral expression. It has normative data for public schools and can be applied with children from 3 to 14 years of age. It consists of 10 subtests (Syllabic Synthesis, Phonemic Synthesis, Rhyming, Alliteration, Syllabic Segmentation, Phonemic Segmentation, Syllabic Manipulation, Phonemic Manipulation, Syllabic Transposition and Phonemic Transposition), containing 2 training items and 4 test items, totaling 40 items. The results are presented as a score or frequency of correct responses, with 40 correct responses being the maximum possible, considering 1 point for each. The application time is estimated at 20 minutes.

Reading and Writing Tasks ${ }^{17}$ : This individual application instrument assesses preliminary abilities of reading and writing of words and pseudowords. It can be applied with children from 3 to 6 years of age. It consists of 20 items (16 words and 4 pseudowords), 10 in the reading part and 10 in the writing part. The items have different linguistic regularities that vary with an increasing degree of complexity in Portuguese Language: a) regular high frequency (e.g., hi, candy and shoe); b) regular low frequency (e.g. day, stalk and Neptune); c) irregular high frequency (e.g. taxi and house); d) irregular low frequency (e.g. swarm and shower); and e) pseudowords (e.g., tami and dofule). In the first part, the child is requested to read the words, one by one; in the second, the child is asked to write the items that are dictated. Correction is carried out considering the percentage of correct responses per item (calculation of the number of letters that the child read and wrote correctly, in the correct sequence expected), ranging from 0 to $100 \%$ in reading and writing (details of the correction criteria can be found in the original article ${ }^{17}$ ). The application time is estimated at 15 minutes.

\section{Statistical analysis}

Prior to the calculation of the standard scores, in order to verify the need and justify the provision/update of the standards, the means of performance of the tests of the current sample were compared with the existing normative data, in the case of the Phonological Awareness Test by Oral Production. Student's t-test was used to compare the performances of the children of the current sample (public vs. private school) in the Phonological Awareness Test by Oral Production and Reading and Writing Tasks. Cohen's d was also calculated for this comparison. Pearson's correlation analysis was performed to verify the relationship between the measures. The performance of the sample of this study in the Phonological Awareness by Oral 
Production was compared to the performance obtained from the standardization sample of the instrument ${ }^{30}$ by means of the Wilcoxon test (comparison of private school vs. normative data, comparison of public school vs. normative data). Finally, with the support of previous analyses on the pertinence of new standards, the standard scores for the Reading and Writing Tasks and Phonological Awareness by Oral Production, considering the two types of school, were calculated from the formula: $\{[($ Gross-score - sample performance mean)/ Standard deviation] $\left.{ }^{*} 15\right\}+100$.

\section{RESULTS}

The comparison of the performances between the public and private school samples in the Phonological
Awareness Test by Oral Production and the Reading and Writing Tasks is presented in Table 2. The children of the private school performed better than those of the public school in all measures, with large effect sizes $(d)$. This result reinforces the need for specific standards according to the type of school for the Phonological Awareness Test by Oral Production and the Reading and Writing Tasks.

In an exploratory way, the relationship between the measures was verified, with strong relationships between the Phonological Awareness Test by Oral Production and the Reading and Writing Tasks (both with $r=0.78, p<0.001)$. The relation between the reading and writing tasks was very strong $(r=0.82$, $p<0.001$ ).

Table 2. Descriptive and inferential (t-test) statistics of the performances in the Phonological Awareness Test by Oral Production and in the Reading and Writing Test, by type of school

\begin{tabular}{ccccccc}
\hline Test & Type of school & Mean & SD & $\boldsymbol{t}$ & $\boldsymbol{p}$ & $\boldsymbol{d}$ \\
\hline Phonological Awareness Test & Private & 18.8 & 7.83 & 9.63 & $<0.001$ & 1.315 \\
by Oral Production & Public & 10.7 & 3.82 & & & \\
Reading and Writing Task/ & Private & 56.7 & 38.10 & 13.81 & $<0.001$ & 1.923 \\
Reading & Public & 2.5 & 11.68 & & & \\
Reading and Writing Task/ & Private & 54.9 & 38.549 & 12.23 & $<0.001$ & \multirow{2}{*}{1.694} \\
Writing & Public & 5.9 & 13.662 & & & \\
\hline
\end{tabular}

The comparison between the performance of the children of the present study and those of the standardized sample in the Phonological Awareness Test by Oral Production revealed significant differences, with better results for the sample of this study (private school and normative data comparison: $Z=-8.683$ and $p \leq 0.001$; public school and normative data comparison: $Z=-9.358$ and $p \leq 0.001)$. The means obtained by the children of each type of school are listed in Table 2; the expected score for children aged 5 years from the existing standards is 7 points (range of 4 to 10 points included in the average classification, with the Wilcoxon test producing the median=7.00). Above all, considering the results of the comparison with the public school children, the finding suggests the need to update the standards of the Phonological Awareness Test by Oral Production.

Table 3 updates the normative data of the Phonological Awareness Test by Oral Production for public school children in this age group and also provides normative data for the private school. Table 4 provides preliminary normative data for the Reading and Writing Tasks for each type of school. 
Table 3. Normative data for the Phonological Awareness Test by Oral Production for private school children and updating of the normative data available for public school children

\begin{tabular}{|c|c|c|}
\hline \multirow{2}{*}{ Gross score } & \multicolumn{2}{|c|}{ Standard score (5 years of age) } \\
\hline & Public School & Private School \\
\hline 1 & 61.9 & 65.9 \\
\hline 2 & 65.8 & 67.9 \\
\hline 3 & 69.7 & 69.8 \\
\hline 4 & 73.7 & 71.7 \\
\hline 5 & 77.6 & 73.6 \\
\hline 6 & 81.5 & 75.5 \\
\hline 7 & 85.4 & 77.4 \\
\hline 8 & 89.3 & 79.3 \\
\hline 9 & 93.3 & 81.2 \\
\hline 10 & 97.2 & 83.2 \\
\hline 11 & 101.1 & 85.1 \\
\hline 12 & 105.0 & 87.0 \\
\hline 13 & 108.9 & 88.9 \\
\hline 14 & 112.9 & 90.8 \\
\hline 15 & 116.8 & 92.7 \\
\hline 16 & 120.7 & 94.6 \\
\hline 17 & 124.6 & 96.6 \\
\hline 18 & 128.5 & 98.5 \\
\hline 19 & 132.5 & 100.4 \\
\hline 20 & 136.4 & 102.3 \\
\hline 21 & 140.3 & 104.2 \\
\hline 22 & 144.2 & 106.1 \\
\hline 23 & 148.2 & 108.0 \\
\hline 24 & 152.1 & 110.0 \\
\hline 25 & 156.0 & 111.9 \\
\hline 26 & 159.9 & 113.8 \\
\hline 27 & 163.8 & 115.7 \\
\hline 28 & 167.8 & 117.6 \\
\hline 29 & 171.7 & 119.5 \\
\hline 30 & 175.6 & 121.4 \\
\hline 31 & 179.5 & 123.3 \\
\hline 32 & 183.4 & 125.3 \\
\hline 33 & 187.4 & 127.2 \\
\hline 34 & 191.3 & 129.1 \\
\hline 35 & 195.2 & 131.0 \\
\hline 36 & 199.1 & 132.9 \\
\hline 37 & 203.1 & 134.8 \\
\hline 38 & 207.0 & 136.7 \\
\hline 39 & 210.9 & 138.7 \\
\hline 40 & 214.8 & 140.6 \\
\hline
\end{tabular}

The standard scores were calculated from the formula: $\left\{\left[\right.\right.$ (Gross-score - sample performance mean)/Standard deviation] $\left.{ }^{*} 15\right\}+100$. 
Table 4. Preliminary normative data of the Reading and Writing Test for public and private schools

\begin{tabular}{cccccc}
\hline \multirow{2}{*}{$\begin{array}{c}\text { Percentage of } \\
\text { correct responses } \\
\text { in Reading }\end{array}$} & \multicolumn{2}{c}{ Standard score (5 years of age) } & Percent of correct & \multicolumn{2}{c}{ Standard score (5 years of age) } \\
& Public School & Private School & Writing & Public School & Private School \\
\hline 0 & 96.7 & 77.7 & 0 & 93.5 & 78.6 \\
1 & 98.0 & 78.1 & 1 & 94.6 & 79.0 \\
2 & 99.3 & 78.5 & 2 & 95.7 & 79.4 \\
3 & 100.6 & 78.9 & 3 & 96.8 & 79.8 \\
4 & 101.9 & 79.3 & 4 & 97.9 & 80.2 \\
5 & 103.2 & 79.7 & 5 & 99.0 & 80.6 \\
6 & 104.4 & 80.1 & 6 & 100.1 & 81.0 \\
7 & 105.7 & 80.4 & 7 & 101.2 & 81.4 \\
8 & 107.0 & 80.8 & 8 & 102.3 & 81.8 \\
9 & 108.3 & 81.2 & 9 & 103.4 & 82.1 \\
10 & 109.6 & 81.6 & 10 & 104.5 & 82.5 \\
15 & 116.0 & 83.6 & 15 & 110.0 & 84.5 \\
20 & 122.4 & 85.6 & 20 & 115.5 & 86.4 \\
25 & 128.8 & 87.5 & 25 & 120.9 & 88.4 \\
30 & 135.3 & 89.5 & 30 & 126.4 & 90.3 \\
35 & 141.7 & 91.5 & 35 & 131.9 & 92.3 \\
40 & 148.1 & 93.4 & 40 & 137.4 & 94.2 \\
45 & 154.5 & 95.4 & 45 & 142.9 & 96.2 \\
50 & 160.9 & 97.4 & 50 & 148.4 & 98.1 \\
55 & 167.3 & 99.3 & 55 & 153.9 & 100.0 \\
60 & 173.8 & 101.3 & 60 & 159.4 & 102.0 \\
65 & 180.2 & 103.3 & 65 & 164.9 & 103.9 \\
70 & 186.6 & 105.2 & 70 & 170.4 & 105.9 \\
75 & 193.0 & 107.2 & 75 & 175.8 & 107.8 \\
80 & 199.4 & 109.2 & 80 & 181.3 & 109.8 \\
85 & 205.8 & 111.2 & 85 & 186.8 & 111.7 \\
90 & 212.3 & 113.1 & 90 & 192.3 & 113.7 \\
95 & 218.7 & 115.1 & 100 & 197.8 & 115.6 \\
100 & 225.1 & 117.1 & 203.3 & 117.6 \\
\hline
\end{tabular}

The standard scores were calculated from the formula: $\{[($ Gross-score - sample performance mean)/Standard deviation $]$ * 15$\}+100$.

\section{DISCUSSION}

Initially, in order to verify the pertinence of the normative data stratified by type of school, the performances of the children from public and private schools in the Reading and Writing Tasks and Phonological Awareness Test by Oral Production were compared. As expected, the private school children outperformed their public school peers in all measures. This finding was expected and may reflect the better quality of stimulation provided by the private institution or that the 'school type' variable can mediate the effect of the socioeconomic status and the quality of stimulation in the family environment, both hypotheses not being exclusive $^{25-27}$. A previous study produced similar results, with better performance of the children of the private school in rapid serial naming and writing. For these authors, this effect would be associated with socioeducational aspects such as the number of books at home and the family reading habits ${ }^{25}$. Another study, with older children of the $1^{\text {st }}$ and $2^{\text {nd }}$ years, showed that the socioeconomic level, especially the income and educational qualification of the parents, was able to explain more than $50 \%$ of the variability in the language, measured in terms of receptive and expressive vocabulary. Socioeconomic status was also related to the children's experiences at home and at school and to their academic performance. However, regardless of the socioeconomic level, the type of school had a fundamental impact on academic performance, with the children of private schools showing better results when 
compared to the children of public schools ${ }^{28}$. In accordance with these findings, the differences observed in the present sample justify the provision of independent standards for children of each type of school.

Once the need for standards by type of school was verified, it was investigated whether there were differences between the performance of the current sample and the sample of standardization of the Phonological Awareness Test by Oral Production for public school, in order to verify whether the updating of the available standards was justified. Although published in 2012, these data were collected in mid-2008, so that approximately 10 years have passed ${ }^{30}$. A significant difference was again observed, with higher performances for the current sample in comparison to the standard. Hypotheses for this can go beyond the Flynn effect (gains verified in measures of cognitive abilities over time) and reflect changes in the practices in Early Childhood Education. For example, in 2010, the Ministry of Education produced a new document that established the National Curriculum Guidelines for Early Childhood Education ${ }^{37}$. The text provides quality references for Early Childhood Education and presents the requirements for an education that allows the integral development of the child up to 5 years of age. Regardless of the mechanism underlying this difference in performance, the fact is that an update of the normative data was found to be necessary, in accordance with prevailing prerogatives in the area of psychological assessment, taken here only as a model.

Strong relationships were found between the measures, which shows the strong association of phonological awareness with reading and writing, even considering initial reading and writing abilities. In fact, there is high consistency of this finding in the literature ${ }^{1,8,12,15,17}$, as well as the predictive power of these abilities in relation to future reading and writing performance in the literacy stage ${ }^{38}$, with some authors suggesting the stimulation of these precursor abilities prior to the formal literacy process ${ }^{12,16}$.

It is precisely the predictive power of these precursor abilities, phonological awareness and early reading and writing abilities that make their evaluation at early ages, prior to formal literacy, relevant. Authors have agreed that these abilities (which include others, such as knowledge of letters and sounds, rapid serial naming etc.) are important acquisitions for the child to learn to read and write effectively ${ }^{1,8,9}$. However, there is a lack of tools available for evaluating them. In the case of phonological awareness, there are already instruments available such as the Phonological Awareness Test by Oral Production ${ }^{36}$ or the Confias Test ${ }^{39}$. In the case of initial reading and writing abilities, this difficulty was highlighted in two recent reviews on reading ${ }^{6}$ and writing ${ }^{7}$ assessment instruments, which evidenced the absence of instruments for the evaluation of precursor or pre-literacy abilities. Recently, however, the Reading and Writing Tasks were made available ${ }^{17}$.

It is in this context that the present study sought to make a contribution by providing normative data updated and stratified by type of school for instruments already available that measure two important reading and writing abilities. The age at which the standards are made available, despite the restricted range, refers to the final level of Early Childhood Education, prior to the child's entry into Elementary School and the formal beginning of literacy.

The study has limitations, such as the absence of auditory screening or a specific auditory evaluation of the children, the restriction of the age group evaluated and absence of other measures, such as intelligence and socioeconomic classification (including income and parental education), which may have mediating and/or moderating effects on the performance in the variables of analysis. Future studies should expand the analysis to other age groups. However, it is important to highlight the possible implications for clinical and/ or school evaluation by instrumentalizing teachers and other professionals that work with the evaluation and early identification of difficulties in reading and writing abilities.

\section{CONCLUSION}

The study provided preliminary normative data for measures of two important precursor abilities of written language for children of the final level of Early Childhood Education. In addition, the performances in early reading, writing, and phonological awareness abilities were compared in children of public and private schools, corroborating other studies ${ }^{25-28}$ which identified that the type of school appears to influence the cognitive performance. In the sample studied, the children of the private school had superior performance in all the measures evaluated, which indicates the importance of normative data stratified by type of school. Specifically, in relation to the normative data of the Phonological Awareness Test by Oral Production already available for public schools, the need to update the standards ${ }^{32,33}$ when comparing them with the results of the present sample, was verified. 
It should be noted that the evaluation of phonological awareness and initial reading and writing abilities at the end of Early Childhood Education can provide indicative information that allows the identification of children at risk for difficulties in reading and writing acquisition in the course of Elementary Education. Therefore, having instruments and normative data that allow the evaluation of these precursor abilities, prior to the period of formal literacy, can help in preventing difficulties and stimulating a posture of abilities promotion in Early Childhood Education.

\section{REFERENCES}

1. Barrera SD, Santos MJ. Conhecimento do nome das letras e habilidades iniciais em escrita. Bol. Acad. Paul. Psicol. 2016;36(90):1-15.

2. Duncan GJ, Dowsett CJ, Claessens A, Magnuson K, Huston AC, Klebanov $P$ et al. School readiness and later achievement. Dev Psychol. 2007;43(6):1428-46.

3. Kim YS, Al Otaiba S, Puranik C, Folsom JS, Gruelich $\mathrm{L}$. The contributions of vocabulary and letter writing automaticity to word reading and spelling for kindergartners. Read writ. 2014;27(2):237-53.

4. Pinto G, Bigozzi L, Vezzani C, Tarchi C. Emergent literacy and reading acquisition: a longitudinal study from kindergarten to primary school. Euro J Psychol Educ. 2017;32(4):571-87.

5. Kendeou P, Van den Broek P, Helder A, Karlsson JA. Cognitive view of reading comprehension: implications for reading difficulties. Learn Disab Res Pract. 2014;29(1):10-6.

6. Dias NM, León CBR, Pazeto TCB, Martins GLL, Pereira APP, Seabra AG. Avaliação da leitura no Brasil: revisão da literatura no recorte 2009-2013. Psicol Teoria Pratica. 2016;18(1):113-28.

7. León CBR, Pazeto TCB, Martins GLL, Pereira APP, Seabra AG, Dias NM. Como avaliar a escrita? Revisão de instrumentos a partir das pesquisas nacionais. Rev Psicopedag. 2016;33(101):331-45.

8. Shanahan T, Lonigan CJ. The national early literacy panel: a summary of the process and the report. Educ Res. 2010;39(4):279-85.

9. NELP: National Early Literacy Panel. Developing early literacy: Report of the National Early Literacy Panel. [2008]. Washington, DC: National Institute for Literacy. Available from http://www.nifl.gov/ earlychildhood/NELP/NELPreport.html

10. Catts HW, Fey ME, Weismer SE, Bridges MS, Tomblin JB, Nippold MA. The relationship between language and reading abilities. In: Tomblin B, Nippold NA (orgs). Understanding individual differences in language development across the school years. New York: Psychology Press; 2014. p. 144-65.

11. Song S, Su M, Kang C, Liu H, Zhang Y, McBrideChang $\mathrm{C}$ et al. Tracing children's vocabulary development from preschool through the school-age years: an 8-year longitudinal study. Dev Science. 2015;18(1):119-31.

12. Rosal AGC, Cordeiro AAA, da Silva ACF, Silva RL, Queiroga BAM. Contributions of phonological awareness and rapid serial naming for initial learning of writing. Rev. CEFAC. 2016;18(1):74-85.

13. Pazeto TCB, Seabra AG, Dias NM. Executive functions, oral language and writing in preschool children: development and correlations. Paidéia. 2014;24(58):213-22.

14. Dambrowski AB, Martins CL, Theodoro JL, Gomes E. Influencia da consciência fonológica na escrita de pré-escolares. Rev. CEFAC. 2008;10(2):175-81.

15. Suortti O, Lipponen L. Phonological awareness and emerging reading skills of two- to five-year-old children. Early Child Dev Care. 2016;186(11):1703-21.

16. Frohlich LP, Metz D, Petermann F. Program for the enhancement of phonological awareness in preschoolers. Kindheit und Entwicklung. 2009;18(4):204-12.

17. Pazeto TCB, León CBR, Seabra AG. Avaliação de habilidades preliminares de leitura e escrita no início da alfabetização. Rev Psicopedag. 2017;34(104):137-47.

18. Costa HC, Perdry H, Soria C, Pulgar S, Cusin F, Dellatolas G. Emergent literacy skills, behavior problems and familial antecedents of reading difficulties: a follow-up study of reading achievement from kindergarten to fifth grade. Res Dev Disabil. 2013;34(3):1018-35.

19. Capovilla AGS, Dias NM. Habilidades de linguagem oral e sua contribuição para a posterior aquisição de leitura. Rev Psic. 2008;9(2):135-44.

20. Puranik CS, Lonigan CJ. From scribbles to scrabble: preschool children's developing knowledge of written language. Read Writ. 2011;24(5):567-89.

21. Cardoso-Martins C, Corrêa MF, Marchetti PMT. O Conhecimento do nome das letras e o desenvolvimento inicial da escrita: o caso do português do Brasil. In: Maluf MR, Guimarães SRK 
(org). Desenvolvimento da linguagem oral e escrita. Curitiba: UFPR; 2008. p. 137-53

22. Cardoso-Martins C, Batista ACE. O conhecimento do nome das letras e o desenvolvimento da escrita: evidência de criança falantes do português. Psic Refl Crít. 2005;18(3):330-6.

23. Levin I, Patel S, Margalit T, Barad N. Letter names: effect on letter saying, spelling, and word recognition in Hebrew. Appl Psycolinguist. 2002;23(2):269-300.

24. Treiman R, Kessler B. The role of letter names in the acquisition of literacy. In: Kail K (org). Advances in child development and behavior. San Diego: Academic Press. 2003. p. 105-35.

25. Silva ACF, Cordeiro AAA, Queiroga BAM, Rosal AGC, Carvalho EA, Roazzi A. Relation between phonological development and writing initial learning in different socio-educational settings. Rev. CEFAC. 2015;17(4):1115-31.

26. Enricone JRB, Salles JF. Relação entre variáveis psicossociais familiares e desempenho em leitura/escrita em crianças. Psicol Escolar Educ. 2011;15(2):199-210.

27. Gonçalves TS, Neves TAP, Nicolielo AP, Crenitte PAP, Lopes-Herrera SA. Phonological awareness in children from public schools and particularly during the process of literacy. Audiol Commun Res. 2013;18(2):78-84.

28. Engel de Abreu PMJ, Tourinho CJ, Puglisi ML, Nikaedo C, Abreu N, Miranda MC et al. Poverty and the mind: a cognitive science perspective. Walferdange, Luxembourg: The University of Luxembourg; 2015.

29. Stein LM. TDE - Teste de Desempenho Escolar: manual para aplicação e interpretação. São Paulo, SP: Casa do Psicólogo;1994.

30. Seabra AG, Dias NM. Avaliação neuropsicológica cognitiva: Linguagem oral. Volume 2. São Paulo: Memnon; 2012.

31. Seabra AG, Dias NM, Capovilla FC. Avaliação neuropsicológica cognitiva: Leitura, escrita e matemática. Volume 3. São Paulo: Memnon; 2013.

32. CFP: Conselho Federal de Psicologia. Resolução CFP no 002/2003. [2003]. Available from https:// site.cfp.org.br/wp-content/uploads/2003/03/ formul\%C3\%A1rio-anexo-res-02-03.pdf

33. Strauss E, Spreen O, Hunter M. Implications of test revisions for research. Psychol Assessment. 2000;12(3):237-44.
34. Knijnik LF, Giacomoni C, Stein LM. Teste de desempenho escolar: um estudo de levantamento. Psico-USF. 2013;18(3):407-15.

35. Giacomoni CH, Athayde ML, Zanon C, Stein LM. Teste do Desempenho Escolar: evidências de validade do subteste de escrita. Psico-USF. 2015;20(1):133-40.

36. Seabra AG, Capovilla FC. Prova de consciência fonológica por produção oral. In: Seabra AG, Dias NM (org). Avaliação neuropsicológica cognitiva: linguagem oral. São Paulo: Memnon; 2012. p.117-22.

37. Brasil. Diretrizes Curriculares Nacionais para a Educação Infantil. Brasília: MEC, 2010. Available from http://ndi.ufsc.br/files/2012/02/DiretrizesCurriculares-para-a-E-I.pdf

38. Pazeto TCB. Predição de leitura, escrita e matemática no ensino fundamental por funções executivas, na linguagem oral e habilidades iniciais de linguagem escrita na educação infantil [Tese]. São Paulo (SP): Universidade Presbiteriana Mackenzie; 2016.

39. Moojen S, Lamprecht R, Santos RM, Freitas GD, Brodacz R, Siqueira M et al. CONFIAS - Consciência fonológica: instrumento de avaliação sequencial. 2a ed. São Paulo: Casa do Psicólogo; 2003. 